\title{
New Generation Roundabout Application A Study Case: Karabuk 100.Year Roundabout
}

\author{
Halil Ibrahim Yumrutas* \\ Civil Engineering Department, Engineering Faculty, Karabuk University, Karabuk, Turkey
}

Submission: September 16, 2019; Published: October 09, 2019

*Corresponding author: Halil Ibrahim Yumrutas, Civil Engineering Department, Engineering Faculty, Karabuk University, Karabuk, Turkey

\begin{abstract}
Roundabouts are common areas formed by the intersection, merging and separation of two or mor

e roads and are one of the most important road parts that constitute various risks in terms of road safety. There are various standard intersection applications in the world and our country. Only capacity analyzes are not enough to determine intersection type. Factors such as traffic safety, land topography, cost, development plans, expropriation, local demands, history, cultural and touristic characteristics of the area, and the requirements of the public authorities are also necessary factors to be assessed. However, traffic problems at intersections, which are designed in a standard way without considering the above-mentioned factors affecting intersection design, require different solutions especially in these parts of highway. In this study, existing problems were identified on the basis of traffic counts and field observations on a sample roundabout in Karabük Province, 100.year neighborhood, at the intersection of 1002 Street and 1003 street. A new intelligent roundabout design was applied and the applicability of the new intersection model in addition to capacity and safety has been demonstrated and optimized using Ptv-Vissim and Autoturn software's. The revealing results are; it is necessary to design the intersections considering the specific parameters of each intersection instead of standardization and it is necessary to adopt new approaches (intelligent crossroads etc.) in intersection design.

Keywords: Intersection; roundabout; Ptv-vissim; Autoturn; roundabout optimization
\end{abstract}

\section{Introduction}

In parallel with the population increase and technological developments in the world and our country, the ownership of motor vehicles increases rapidly, and this causes various traffic problems. The high rates of accidents in road parts which traffic flows intersect and called intersection or crossroad reveals that these parts need to be considered more carefully in terms of traffic safety.

Crossroads are common areas formed by the intersection, merging and separation of two or more roads. Crossroads are designed taking into consideration the terrain conditions, traffic volume and traffic safety reasons, such as ensuring continuity of intersecting traffic flows on main and secondary roads, increasing safety, controlling speed, reducing delays caused by slowing and stopping, ensuring adequate service level, reducing vehicle operation costs. They have different kinds such as; at grade, interchange, three-armed, four-armed, multi-armed, rotary, channeled, etc. [1].

In intersection designs; traffic factor (current and design capacity, traffic volume values including return traffic, peak hour traffic values), physical factors (geometric characteristics of intersection area, environmental factors, property and zoning status, safety criteria, traffic signs and lighting equipment's, pedestrian crossings, pedestrian movements, number of traffic accidents), economic factors (construction cost, construction and expropriation constraints and costs, maintenance/repairoperation cost) and social factors (demographic structure, public opinion). The most important factors affecting the accidents in intersections are; intersection geometry (number of intersection arms, horizontal angle of intersection arms, sight distance and sight blinder), channeling, distance to previous intersection, intersection approach line, platform and platform widths, longitudinal slope, middle refuge width, surface condition, the effects of highway and highway traffic volume and heavy vehicle percentage, the effect of speed, the effect of enlightenment, the effect of daytime conditions, the effect of weather [2].

Between 2006 and 2015, 14 European Union countries had lost 64,171 lives due to the accidents in intersections, which means $22 \%$ of all accidents. In 2004, 27.43\% of the 1.2 million accidents occurred in the crossroads in Europe [3,4]. Crossroads accidents in the USA are $50 \%$ of total city accidents and $30 \%$ of intercity accidents [5]. In a study conducted by technology 


\section{Civil Engineering Research Journal}

research collaboration members, it was found that in 2002, 50\% of the total accidents occurred at intersections [6]. According to the OECD scientific expert group, the risk of injury in an hour of traffic accidents is 30 times higher than that of a working worker. In addition, while the situation in developed countries in relation to traffic accidents is improving, the situation is getting worse in developing countries due to various negativities [2].
Traffic problems in developing countries such as our country are increasing day by day and this situation can be observed more clearly when traffic statistics are compared. Table 1 lists the number of developed Baltic States and the number of vehicles in our country and the mortality rates associated with them. In developed countries, traffic accidents and mortality rates are relatively low compared to country numbers compared to vehicle numbers.

Table 1: The numbers of vehicles in the Baltic States and our country and the mortality rates in traffic accidents [7].

\begin{tabular}{|c|c|c|c|c|c|c|}
\hline $\begin{array}{c}\text { Name of Country/Pop- } \\
\text { ulation }\end{array}$ & Year & Number of Vehicles & Accidents & $\begin{array}{c}\text { Number of } \\
\text { Death }\end{array}$ & $\begin{array}{c}\text { Number of } \\
\text { Injured }\end{array}$ & $\begin{array}{c}\text { Death rates compared to number of } \\
\text { vehicles (\%) }\end{array}$ \\
\hline Turkey 74.724 .269 & 2010 & 15.095 .603 & 126.804 & 3.215 & 211.496 & 0,020 \\
\hline Denmark 5.432.335 & 2010 & 2.846 .699 & 4.408 & 255 & 4.153 & 0,008 \\
\hline $\begin{array}{c}\text { Swedish } \\
9.325 .429\end{array}$ & 2010 & 5.203 .862 & 45 & 314 & 26 & 0,006 \\
\hline Norway 4.885.240 & 2011 & 2.900 .000 & 8.976 & 169 & 8.569 & 0,005 \\
\hline
\end{tabular}

In Table 2, traffic accident information was given to $28 \mathrm{EU}$ member countries. According to this; It has been observed that the number of mortal and injured accidents in our country and the number of deaths per million people are far higher than the average of the Member States of the Union, which is an indication that urgent precautions should be taken.

\begin{tabular}{|c|c|c|c|c|c|}
\hline accident & information & mortality & rates & European & ntries \\
\hline Country & $\begin{array}{l}\text { Accidents involving de- } \\
\text { ath or personal injury }\end{array}$ & Deaths & $\begin{array}{c}\text { Automobi- } \\
\text { le per *10 } \\
\text { people }\end{array}$ & $\begin{array}{c}\text { Deaths per } * 10^{6} \text { auto- } \\
\text { mobiles }\end{array}$ & $\begin{array}{l}\text { Deaths per } \\
10^{6} \text { people }\end{array}$ \\
\hline Türkiye & 185,128 & 7,300 & 142 & 645 & 91 \\
\hline Germany & 302,435 & 3,377 & 547 & 77 & 42 \\
\hline Austria & 37,957 & 430 & 547 & 92 & 50 \\
\hline Belgium & 41,481 & 727 & 495 & 131 & 65 \\
\hline Bulgaria & 7,015 & 661 & 418 & 223 & 92 \\
\hline Czech Republic & 21,054 & 688 & 459 & 144 & 65 \\
\hline Denmark & 2,881 & 182 & 412 & 79 & 32 \\
\hline Esthonia & 1,436 & 78 & 497 & 122 & 59 \\
\hline Finland & 5,324 & 229 & 581 & 73 & 42 \\
\hline France & 58,191 & 3,384 & 479 & 107 & 51 \\
\hline Greek cypriot admin.of southern cyprus & 758 & 45 & 565 & 94 & 53 \\
\hline Croaita & 10,323 & 308 & 349 & 211 & 73 \\
\hline Holland & 13,358 & 477 & 472 & 60 & 28 \\
\hline England & 152,407 & 1,854 & 472 & 61 & 29 \\
\hline Ireland & 5,405 & 193 & 425 & 99 & 42 \\
\hline Spain & 91,570 & 1,688 & 474 & 77 & 36 \\
\hline Sweden & 13,091 & 270 & 470 & 59 & 28 \\
\hline Italy & 177,031 & 3,381 & 610 & 91 & 56 \\
\hline Latvia & 3,728 & 212 & 331 & 328 & 106 \\
\hline Lithuania & 3,256 & 267 & 413 & 177 & 91 \\
\hline Luxemburg & 908 & 35 & 662 & 95 & 63 \\
\hline Hungary & 15,847 & 626 & 316 & 204 & 63 \\
\hline Malta & 1,449 & 10 & 619 & 38 & 23 \\
\hline Poland & 34,970 & 3,202 & 526 & 163 & 84 \\
\hline
\end{tabular}




\section{Civil Engineering Research Journal}

\begin{tabular}{|c|c|c|c|c|c|}
\hline Portugal & 30,604 & 638 & 433 & 142 & 61 \\
\hline Romania & 25,355 & 1,818 & 247 & 379 & 152 \\
\hline Slovakia & 5,064 & 291 & 360 & 101 & 54 \\
\hline Slovenia & 6,168 & 108 & 518 & 155 & 73 \\
\hline Greece & 11,690 & 795 & 472 & 104 & 51 \\
\hline
\end{tabular}

In our country, there are very little studies on urban intersection geometry and safety $[7,8]$. The most important reason for this is that the intersection geometry is not included in the accident logs in detail, which makes it difficult to determine the effect on the accidents. However, when a number of statistics are examined, it is seen that a significant part of the numbers of the accidents which are already high enough in our country have come to the crossroads. According to statistics in our country, $40 \%-60 \%$ of traffic accidents occur at intersections of urban and rural roads. Even though the crossroads physically cover only a small part of the road system, it is seen that the number of accidents that occurred at crossroads in international studies is considerably high [2].

In 2016 , there are 52,414 accidents in our country, and there are 3960 dead and 109,839 injured in these accidents. Only these figures show that the problem of traffic safety at intersections is important and a matter of solution [9].

However, by evaluating the effective parameters on the intersections, positive results are obtained with the help of various statistics. In a study in the United States, 11 intersections were revised as roundabouts, resulting in $37 \%$ reduction in total accidents and 51\% reduction in injuries [10]. Also in a study in the United States, the revisions in the geometric designs of different types of intersections in different regions were observed for 2 years and the results showed that the rates of accident at intersections dropped significantly [11]. Gates \& Maki [12] investigated the accident statistics of two intersection types after reconstructing an old type rotary junction in the University of Michigan as a modern roundabout and found that there was a decrease in the number of accidents after the application [12].

Sisiopiku \& Oh [13] reported that roundabouts perform better than signal-controlled junctions and should be considered in intersection designs [13]. Tollazzi et al. [14] study, they have reduced the problematic parts (knitting, overlapping, separation) in the intersection by developing a kind of roundabout that they gave the name of the flower island, thus decreasing the time losses and accident rates and increasing the intersection capacity [14]. Gross et al. [15] found that the signalized junction had more capacity after the redesign as a modern roundabout, but the modern roundabouts were more reliable in terms of number of injuries and fatal accidents [15]. The historic roundabout concept, as well as the date of the historic roundabouts, was first introduced by the French architect Eugene Henard in 1877 [16]
In 1903, it was suggested that the roundabout as an intersection of multiple roads is a suitable traffic control method. The roundabouts were first used in New York in 1905. Later on, these junctions spread to many countries, especially in the UK, in a very short time. With the high rate of accidents and congestion being seen, the design of these intersections has been changed since the mid1950s. Especially in the big cities, the congestion in the city intersections and the arrival of the delays to large dimensions together with the traffic in the intersections for the first time have been discussed and consequently, the "round route around the island" has been applied in the present roundabouts. According to statistical information in the countries where it is practiced, modern roundabouts that significantly reduce the number and severity of traffic accidents are preferred in many European countries, the US, Canada, Australia and some African countries $[17,18]$. When viewed roundabouts in Turkey seems to be a lot of legacy applications roundabouts. The absence of a specific standard in the design and operation of existing rotary junctions makes the driver's perception and behavior difficult [17]. This situation leads to more irregularities, especially in the inner-city roundabouts. In addition, by causing a chaos within the intersection, stress, aggressiveness, etc. on the drivers phsychological negative effects.

European Union countries, USA etc. a standard similar to the standards prepared for the design, control and management of such junctions in the countries which have been put into implementation of the modern roundabout is unfortunately not available for our country. In particular, signaling applications are considered as the only solution to intersection problems and the results obtained from practice are usually far from expectant. Incorrect signal-to-turn junction design has increased stopping points, which have resulted in no reduction in latency, number of accidents, congestion, and number of drive failures [19].

In Saplioglu \& Karasahin [2] study, the effects of road and environment elements, especially intersection geometric features and effects on accidents were investigated in detail, except for human element and vehicle element which cause intersection accidents without signaling in city. The main problem is that the relations between the parameters of the boundary values that should be at an ideal intersection by specifying that they are not formed in a way have revealed the interaction and connection between the elements that affect the intersectional accidents [2]. It is thought that this study will bring a different point of view to solve traffic safety problem at intersections. 


\section{Civil Engineering Research Journal}

\section{Study Area}

The study area is located within the boundaries of the 100 . year neighborhood of Karabük province and is the intersection point of the 1002 and 1003 streets. It is called the 100. year roundabout. The roads connected to the 100 . year roundabout are the most important arteries of the region. Through the north of the study area there are cafes, dormitories, markets; west of the study area there are mosque and dormitories; east of the study area there are post office, mosque, bazaar and south of the study area there are Karabük University and accommodations for students. Also 100. year neighborhood is home to Karabük University with its 56.000 students. Most of the students are accommodated in this region and therefore the car / pedestrian density is available at the intersection almost every hour of the day. There are no signalized junctions in the study area. Figure 1a shows the current map of the study area, Figure $1 \mathrm{~b}$ shows the satellite view, and Figure 1c shows the photographs.

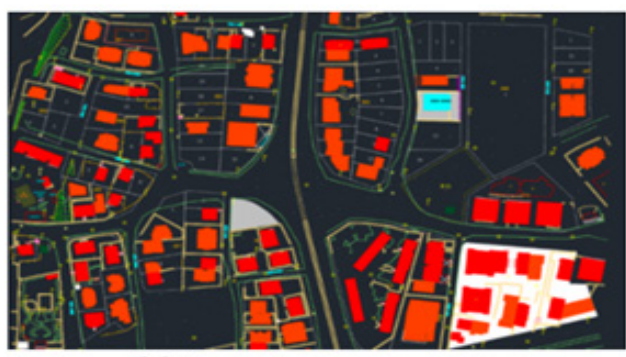

(a) Current map

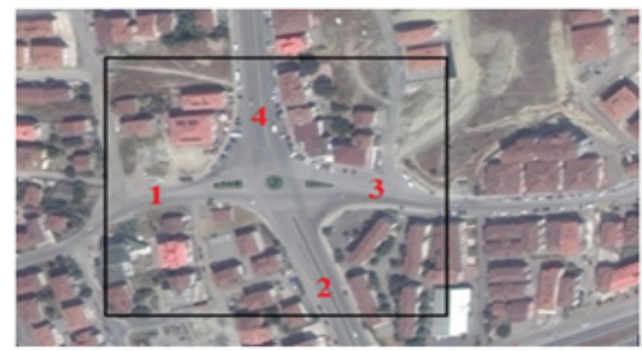

(b) Satellite image

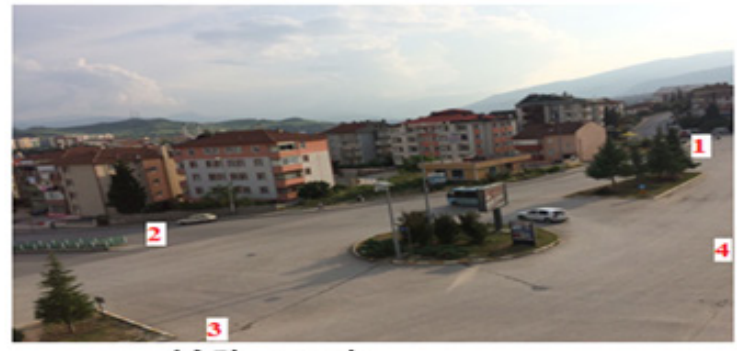

(c) Photograph

Figure 1: The current map, satellite image and photograph of the study area.

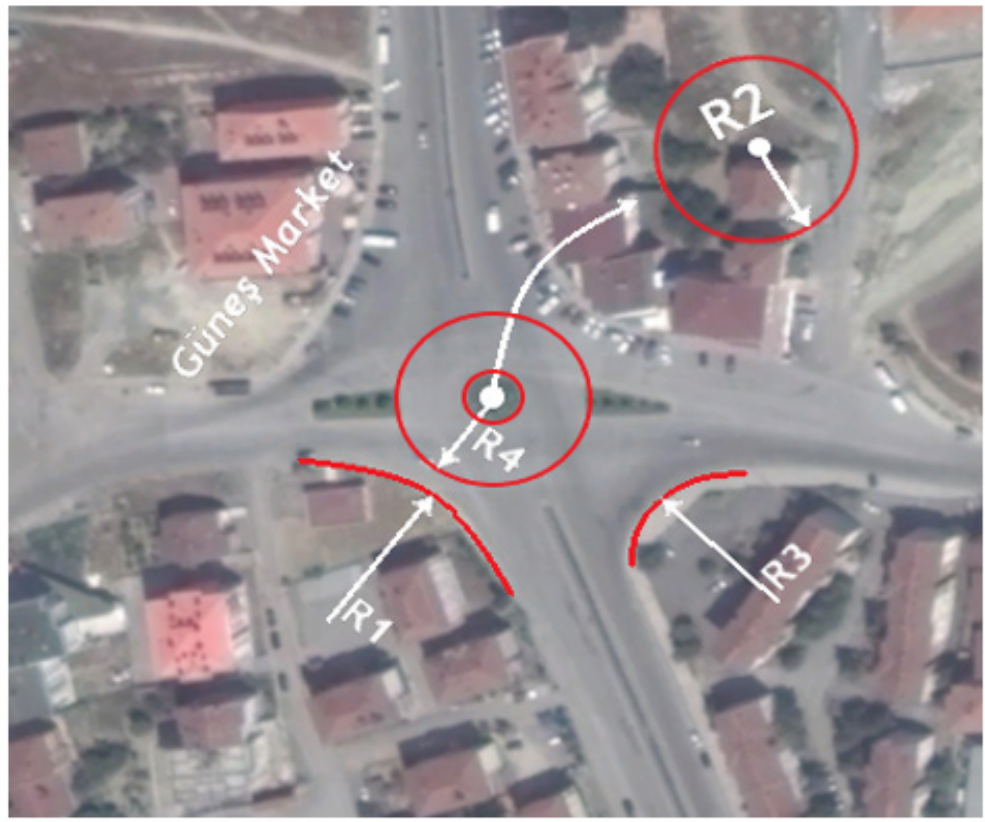

Figure 2: Geometrical parameters of the roundabout. 


\section{Civil Engineering Research Journal}

In Figure 2, the radiuses forming the junction are shown. According to this;
a. $\mathrm{R} 1=40 \mathrm{~m}$
b. $\quad \mathrm{R} 2=6,5 \mathrm{~m}$ (inner radius)
c. $\mathrm{R} 3=30 \mathrm{~m}$
d. $\quad \mathrm{R} 4=28 \mathrm{~m}$ (outer radius)
e. $\quad \mathrm{R} 5=30 \mathrm{~m}$

\section{Definition of the Problem}

As a result of the traffic counts and field observations in the study area, the following problems were identified and it was observed that the intersection capacity could not be used adequately, the time loss, traffic accidents occurred;

i. The study area is exposed to intense pedestrian traffic because it is an area where students are heavily resident, but on-site inspections do not show pedestrian lines. In addition, there is an open stream channel along the north- south direction street 1003 and because of the canal, the street is divided into two, but because there is not enough pedestrian crossing, the pedestrian circulation is collected only at a limited number of places, which causes increase of pedestrian density and negative effect of vehicle traffic. In Figure 3a, because of irregularities and uncontrollable pedestrian transitions, Figure $3 \mathrm{~b}$ shows a limited number of pedestrian crossings on river channel and inadequate width.

ii. Transition priority cannot be understood by the drivers because of the widths of the intersection arms and horizontal / vertical markings, which causes time loss due to unnecessary stop / start or braking and increases the likelihood of an accident.

iii. Due to the lack of adequate shelter pockets reserved for community transport vehicles, the flow of vehicle traffic is blocked, and queues are experienced during passenger loading and unloading processes of buses and minibuses, which is shown in Figure 4.

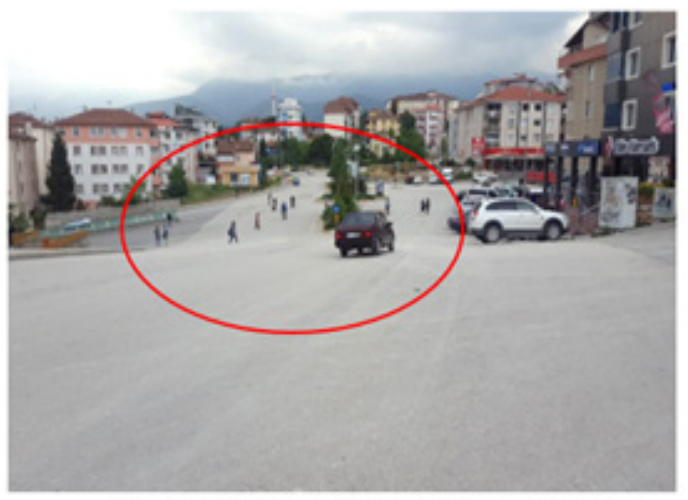

(a) Uncontrolled pedestrian crossing

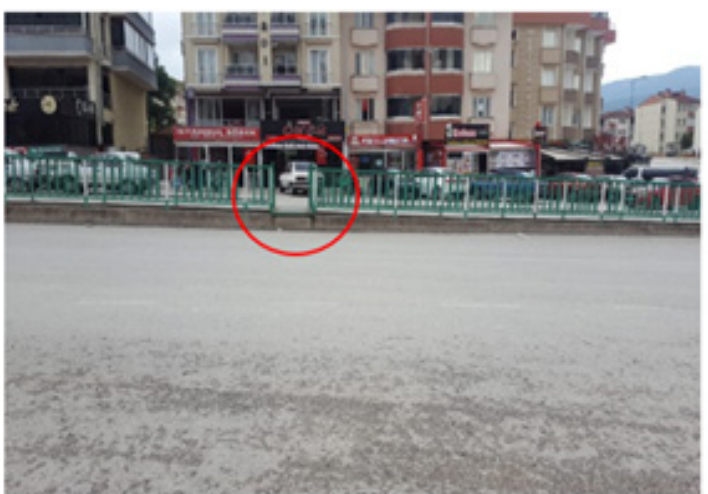

(b) Pedestrian crossing platform on the canal

Figure 3: Pedestrian transition problems in the study area.

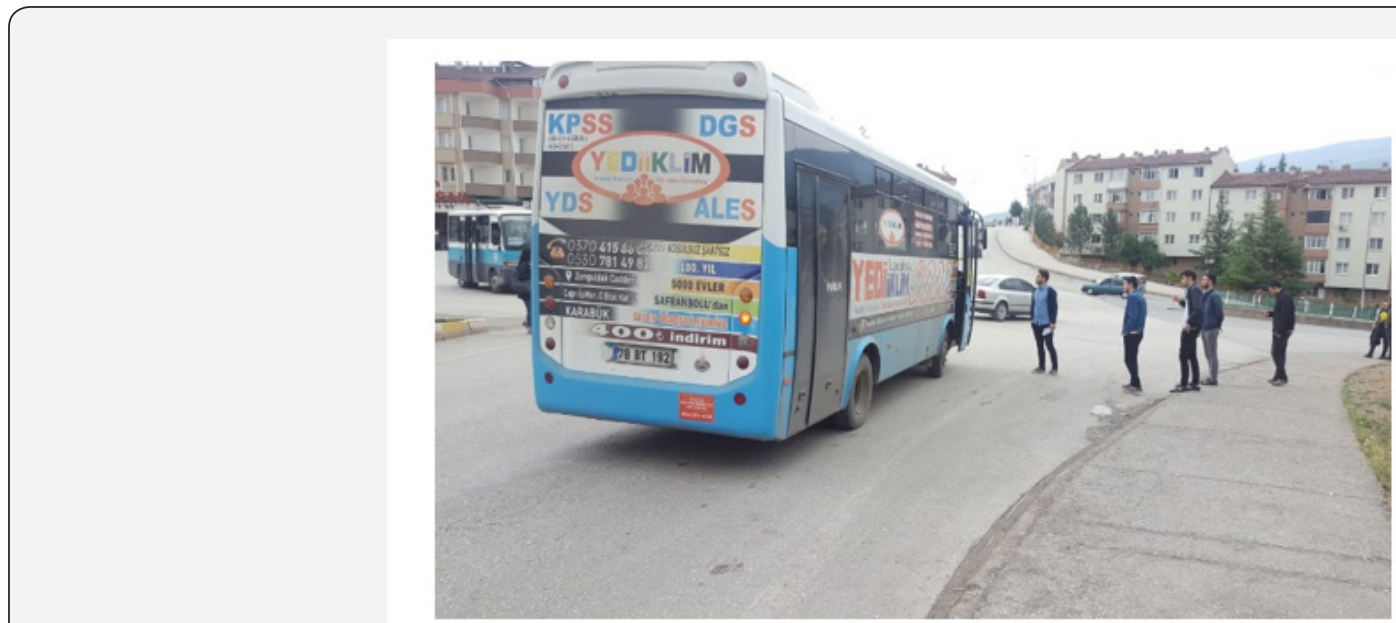

Figure 4: Uncontrolled public transport stops in the work area. 


\section{Civil Engineering Research Journal}

iv. There is no plan for pedestrianization.

v. In other words, traffic flow can be prevented due to lack of parking lines, lack of parking lines and unconscious and random parking along the intersection forming streets, the capacities of the roads cannot be used adequately and this situation also affects the intersection capacity negatively

\section{Materials and Methods}

On the study area, on weekdays 07.05.2018 Monday, on weekends 05.05.2018 Saturday in the peak hours 08:00-09:00, 12:00-13:00 and 20:00-21:00, traffic counts were made. The results show that weekday and weekend traffic values are very close to each other and that the highest traffic density value is between 20:00-21:00 hours during the day. For this reason, for the optimization of the new intersection design 07.05.2018 Monday between 20:00 and 21:00 peak hour values were applied

\section{Vehicle counts}

On weekdays, on 07.05.2018 Monday, for 08:00-09:00, 12:0013: 0 and 20:00-21:00 peak hours, the vehicle count information obtained from the study area is presented in Tables3-5.

Table 3: Vehicle counts from 08:00 to 09:00 Monday morning.

\begin{tabular}{|c|c|c|c|c|}
\hline KAVSAĞIN ADI & \multicolumn{2}{|c|}{ 100.YIL DÖNEL KAVȘAĞI } & \multirow{4}{*}{\multicolumn{2}{|c|}{$\begin{array}{l}\text { KARABÜK ÜNIVERSITESİ MÜHENDİSLİK } \\
\text { FAKÜLTESİ ULASSTIRMA MÜHENDİSLIG̈I } \\
\text { ARAÇ SAYIM TUTANAGI }\end{array}$}} \\
\hline \begin{tabular}{|l|} 
TARIH \\
\end{tabular} & \multirow{2}{*}{\multicolumn{2}{|c|}{$\begin{array}{c}7.5 .2018 \\
08: 00-09: 00\end{array}$}} & & \\
\hline SAAT & & & & \\
\hline HAVA DURUMU & \multicolumn{2}{|c|}{$11^{\circ}$} & & \\
\hline \multicolumn{5}{|c|}{ 100.YIL DŐNEL KAVȘAĞI ARAÇ SAYIM TUTANAĞI } \\
\hline AKIȘ YÖNÜ & $\begin{array}{c}\text { OTOMOBIL/TAKSI// } \\
\text { KAMYONET/PANELVAN }\end{array}$ & $\begin{array}{c}\text { KISA } \\
\text { OTOBǗS/MíNiBŪS/S } \\
\text { ERVIS/MiDiBÜ's }\end{array}$ & $\begin{array}{c}\text { KÖRÖKLÛ̃ OTOBÜS/TIR/KAMYON/SS } \\
\text { MAKINESİ/UZUN OTOBÜS }\end{array}$ & TOPLAM \\
\hline $\begin{array}{l}\text { 1-1 YÖNÜ } \\
\text { (U DÖNÜs) }\end{array}$ & 0 & 0 & 0 & 0 \\
\hline 1-2 YÖNÜ & 92 & 80 & 27 & 199 \\
\hline 1-3 YÖNUี & 100 & 69 & 11 & 180 \\
\hline 1-4 YÖNÜ & 51 & 40 & 4 & 95 \\
\hline 2-1 YÖNÜ & 81 & 19 & 17 & 117 \\
\hline $\begin{array}{l}\text { 2-2 YÖNÜ } \\
\text { (U DÖNÜS) }\end{array}$ & 20 & 1 & 12 & 33 \\
\hline 2-3 YÖNÜ & 209 & 89 & 5 & 303 \\
\hline 2-4 YÖNÜ & 160 & 30 & 9 & 199 \\
\hline 3-1 YÖNÜ & 62 & 44 & & 106 \\
\hline 3-2 YÖNÜ & 200 & 69 & 11 & 280 \\
\hline 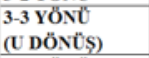 & 5 & 6 & 0 & 11 \\
\hline 3-4 YÖNÜ & 101 & 56 & 23 & 180 \\
\hline 4-1 YÖNÜ & 72 & 18 & 2 & 92 \\
\hline 4-2 YÖNŬ & 40 & 36 & 24 & 100 \\
\hline 4-3 YÖNÜ & 40 & 84 & 6 & 130 \\
\hline $\begin{array}{l}\text { 4-4 YÖNÜ } \\
\text { (U DÖNÜSS) }\end{array}$ & 3 & 5 & 1 & 9 \\
\hline TOPLAM & 1236 & 646 & 152 & 2034 \\
\hline
\end{tabular}

Table 4: Vehicle counts from 12:00 to 13:00 Monday noon.

\begin{tabular}{|c|c|c|c|c|}
\hline KAVŞAĞIN ADI & \multicolumn{2}{|c|}{ 100.YIL DŌNEL KAVŞAĞI } & \multirow{4}{*}{\multicolumn{2}{|c|}{$\begin{array}{l}\text { KARABÜK ÛNIVERSITESI MÜHENDISLIK } \\
\text { FAKÜLTESİ ULASSTIRMA MÜHENDISLIGI } \\
\text { ARAÇ SAYIM TUTANAGI }\end{array}$}} \\
\hline TARIH & \multicolumn{2}{|c|}{7.5 .2018} & & \\
\hline SAAT & \multirow{2}{*}{\multicolumn{2}{|c|}{$\frac{12: 00 \cdot 13: 00}{11^{\circ}}$}} & & \\
\hline HAVA DURUMU & & & & \\
\hline \multicolumn{5}{|c|}{ 100.YIL DŌNEL KAVSSAǴI ARAÇ SAYIM TUTANAĞI } \\
\hline AKIŞ YōNÛ̉ & $\begin{array}{l}\text { OTOMOBIL/TAKSi/ } \\
\text { KAMYONET/PANELVAN }\end{array}$ & 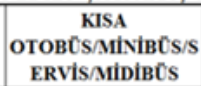 & 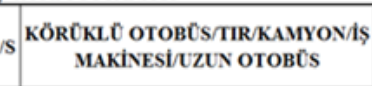 & TOPLAM \\
\hline $\begin{array}{l}\text { 1-1 YŌNŌ } \\
\text { (U DöNరิș) }\end{array}$ & 2 & & 1 & 3 \\
\hline $1-2$ YŌNOั & 84 & 18 & 3 & 105 \\
\hline $1-3$ YöNÖ & 36 & 4 & 0 & 40 \\
\hline 1.4 YôNŌ & 56 & 24 & 9 & 89 \\
\hline 2-1 YồVరิ & 34 & 26 & 2 & 62 \\
\hline $\begin{array}{l}\text { 2-2 YŌNŨ் } \\
\text { (U DÖNÜSS) }\end{array}$ & 12 & 16 & 8 & 36 \\
\hline $2-3$ YŐNÖ & 96 & 22 & 2 & 120 \\
\hline $2-4$ YŌNÔ & 60 & 18 & 6 & 84 \\
\hline 3-1 YÖNరิ & 18 & 12 & 4 & 34 \\
\hline 3-2 YŐNÕ & 88 & 34 & 4 & 126 \\
\hline 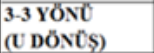 & 12 & 3 & 0 & 15 \\
\hline 3.4 YôNŌ & 43 & 36 & 8 & 87 \\
\hline 4-1 YŐNÜ & 29 & 18 & 4 & 51 \\
\hline 4-2 YöN0̈ & 40 & 23 & 2 & 65 \\
\hline 4-3 YÖN0ี & 38 & 30 & 3 & 71 \\
\hline 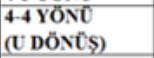 & 30 & 22 & 9 & 61 \\
\hline TOPLAM & 678 & 306 & 65 & 1049 \\
\hline
\end{tabular}




\section{Civil Engineering Research Journal}

Table 5: Vehicle count from Monday to Friday from 20:00 to 21:00.

\begin{tabular}{|c|c|c|c|c|}
\hline KAVSAGĞIN ADI & \multicolumn{2}{|c|}{ 100.YIL DÖNEL KAVŞAĞI } & \multirow{4}{*}{\multicolumn{2}{|c|}{$\begin{array}{l}\text { KARABÜK ÜNIVERSITESI MÜHENDISLIK } \\
\text { FAKÜLTESİ ULASTTIRMA MÜHENDISLIG̈I } \\
\text { ARAÇ SAYIM TUTANAGI }\end{array}$}} \\
\hline TARIH & & & \\
\hline SAAT & & & & \\
\hline HAVA DURUMU & \multicolumn{2}{|c|}{$\frac{20: 00-21: 00}{11^{\circ}}$} & & \\
\hline \multicolumn{5}{|c|}{ 100.YIL DŐNEL KAVȘAĞI ARAÇ SAYIM TUTANAĞI } \\
\hline AKIȘ YÖNÛ̃ & \begin{tabular}{|c|} 
OTOMOBIL/TAKSi// \\
KAMYONET/PANELVAN
\end{tabular} & 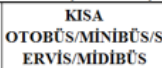 & 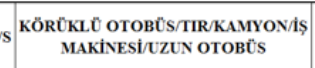 & TOPLAM \\
\hline $\begin{array}{l}\text { 1-1 YÖNÖ } \\
\text { (U DÖNÜS) }\end{array}$ & 6 & & 0 & 6 \\
\hline $1-2$ YöNÜ & 121 & 58 & 13 & 192 \\
\hline $1-3$ YöN & 195 & 5 & 7 & 207 \\
\hline $1-4$ YÖNÖ & 90 & 4 & 9 & 103 \\
\hline $2-1$ YÖNÜ & 90 & 11 & 7 & 108 \\
\hline $2-2$ YONU & 20 & & 8 & 28 \\
\hline 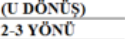 & 264 & 122 & 77 & 463 \\
\hline $2-4$ YÖNỒ & $\frac{0.4}{101}$ & 62 & 17 & 180 \\
\hline 3-1 YöNUั & 69 & 35 & 4 & 108 \\
\hline 3-2 YÖNŨ & 189 & 101 & 39 & 329 \\
\hline $\begin{array}{l}\text { 3-3 YöNŨ } \\
\text { (U DÖNÛ́S) }\end{array}$ & 46 & 3 & 0 & 49 \\
\hline 3-4 YÖNÜ & 140 & 36 & 1 & 177 \\
\hline 4-1 YöNŨ் & 61 & 28 & 12 & 101 \\
\hline 4-2 YÖNÖ & 150 & 36 & & 186 \\
\hline $4-3$ YÖNÖ & 121 & 50 & 5 & 176 \\
\hline 4-4 YÖNŬ & 10 & 2 & 0 & 12 \\
\hline TOPLAM & 1673 & 553 & 199 & 2425 \\
\hline
\end{tabular}

On the weekend, on 05.05.2018 Saturday for 08:00- count information obtained from the study area is presented in 09:00,12:00-13:00 and 20:00-21:00 peak hours the vehicle Tables 6-8.

Table 6: Vehicle counts from 08: 00-09: 00 on Saturday morning.

\begin{tabular}{|c|c|c|c|c|}
\hline KAVSSAĞIN ADI & \multicolumn{2}{|c|}{ 100.YIL DÖNEL KAVŞAĞI } & \multirow{3}{*}{\multicolumn{2}{|c|}{$\begin{array}{l}\text { KARABÜK ÜNIVERSITESİ MÜHENDİSLIK } \\
\text { FAKÜLTESİ ULASTTIRMA MÜHENDISLIGII } \\
\text { ARAÇ SAYIM TUTANAGI }\end{array}$}} \\
\hline TARIH & \multicolumn{2}{|c|}{5.5 .2018} & & \\
\hline SAAT & \multicolumn{2}{|c|}{$08: 00 \cdot 09: 00$} & & \\
\hline HAVA DURUMU & & & \\
\hline \multicolumn{5}{|c|}{ 100.YIL DŌNEL KAVȘAĞI ARAÇ SAYIM TUTANAĞI } \\
\hline AKIS YÖNŨ & $\begin{array}{c}\text { OTOMOBIL/TAKSi/ } \\
\text { KAMYONET/PANELVAN }\end{array}$ & 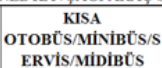 & 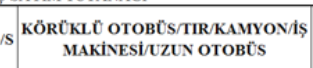 & TOPLAM \\
\hline $\begin{array}{l}\text { 1-1 YÖNŨ } \\
\text { (U DÖNÜ's) }\end{array}$ & 0 & 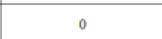 & 0 & 0 \\
\hline 1-2 YÖNÜ & 95 & 81 & 25 & 201 \\
\hline 1-3 YÖNÜ & 100 & 70 & 9 & 179 \\
\hline 1-4 YÖNŬ & 55 & 38 & 2 & 95 \\
\hline 2-1 YÖNÜ & 83 & 21 & 17 & 121 \\
\hline $\begin{array}{l}2-2 \text { YÖNÜ } \\
\text { U DÖNÖS }\end{array}$ & 20 & 3 & 16 & 39 \\
\hline $2-3$ YöNÛ & 209 & 89 & 8 & 306 \\
\hline $2-4$ YÖNÜ & 160 & 27 & 9 & 196 \\
\hline 3-1 YÖNŬ & 68 & 44 & & 112 \\
\hline 3-2 YÖNÜ & 200 & 69 & 11 & 280 \\
\hline 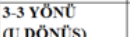 & 9 & 12 & 0 & 21 \\
\hline$\frac{(\text { U DÖNÜS) }}{3-4 \text { YÖNÜ }}$ & 101 & 59 & 23 & $\frac{21}{183}$ \\
\hline 4-1 YÖNÖ́ & 72 & 17 & $\frac{23}{5}$ & 94 \\
\hline $4-2$ YöNOU & 40 & 36 & 24 & 100 \\
\hline $4-3$ YÖNÖ & 42 & 84 & 6 & 132 \\
\hline $\begin{array}{l}\text { 4-4 YÖNÖ } \\
\text { (U DÖNÜS) }\end{array}$ & 8 & 5 & 0 & 13 \\
\hline TOPLAM & 1262 & 655 & 155 & 2072 \\
\hline
\end{tabular}

Table 7: Vehicle count from Saturday noon to 12: 00-13: 00.

\begin{tabular}{|c|c|c|c|c|}
\hline KAVȘAĞIN ADI & \multicolumn{2}{|c|}{ 100.YIL DÖNEL KAVŞAĞI } & \multirow{4}{*}{\multicolumn{2}{|c|}{$\begin{array}{l}\text { KARABÜK ÜNIVERSITESİ MÜHENDİSLIK } \\
\text { FAKÜLTESİ ULASSTIRMA MÜHENDİSLIG̈I } \\
\text { ARAÇ SAYIM TUTANAGI }\end{array}$}} \\
\hline TARIH & \multirow{2}{*}{\multicolumn{2}{|c|}{\begin{tabular}{|c|}
5.5 .2018 \\
$12: 00-13: 00$ \\
\end{tabular}}} & & \\
\hline SAAT & & & & \\
\hline HAVA DURUMU & \multicolumn{2}{|c|}{$13^{\circ}$} & & \\
\hline \multicolumn{5}{|c|}{ 100.YIL DÖNEL KAVȘAǴ̛I ARAÇ SAYIM TUTANAĞI } \\
\hline AKIȘ YÖNŨ & $\begin{array}{l}\text { OTOMOBIL/TAKSİ/ } \\
\text { KAMYONET/PANELVAN }\end{array}$ & 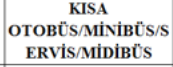 & //S $\begin{array}{c}\text { KÖRÜKLŬ OTOBÜ's/TIR/KAMYON/Ș } \\
\text { MAKINESII/UZUN OTOBÜS }\end{array}$ & TOPLAM \\
\hline $\begin{array}{l}\text { 1-1 YöNOŨ } \\
\text { (U DOONUÛ) }\end{array}$ & 2 & 5 & 1 & 8 \\
\hline 1-2 YÖNÜ & 90 & 18 & 5 & 113 \\
\hline 1-3 YÖNŬ & 36 & 7 & & 43 \\
\hline 1-4 YÖNÜ & 58 & 24 & 9 & 91 \\
\hline 2-1 YÖNŨ & 34 & 26 & 2 & 62 \\
\hline $\begin{array}{l}\text { 2-2 YÖNŬ } \\
\text { (U DÖNŬ́S) }\end{array}$ & 12 & 18 & 8 & 38 \\
\hline 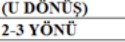 & 96 & 22 & 2 & 120 \\
\hline $2-4$ YÖNUี & 60 & 18 & 6 & 84 \\
\hline 3-1 YÖNŬ & 18 & 12 & 5 & 35 \\
\hline 3-2 YÖNÜ & 90 & 34 & 4 & 128 \\
\hline $\begin{array}{l}\text { 3-3 YÖNÜ } \\
\text { (U DÖNỨS) }\end{array}$ & 12 & 3 & 0 & 15 \\
\hline 3-4 YÖNŬ & 43 & 40 & 8 & 91 \\
\hline 4-1 YÖNUี & 35 & 18 & 4 & 57 \\
\hline 4-2 YÖNŬ & 40 & 23 & 2 & 65 \\
\hline 4-3 YÖNŬ & 38 & 30 & 3 & 71 \\
\hline 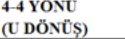 & 30 & 27 & 9 & 66 \\
\hline TOPLAM & 694 & 325 & 68 & 1087 \\
\hline
\end{tabular}




\section{Civil Engineering Research Journal}

Table 8: Vehicle counts between 20: 00-21: 00 on Saturday and evening.

\begin{tabular}{|c|c|c|c|c|}
\hline KAVȘAĞIN ADI & \multicolumn{2}{|c|}{ 100.YIL DÖNEL KAVŞAĞI } & \multirow{4}{*}{\multicolumn{2}{|c|}{$\begin{array}{l}\text { KARABÜK ÜNIVERSITESİ MÜHENDİSLIK } \\
\text { FAKÜLTESİ ULAŞTIRMA MÜHENDİSLİĞ } \\
\text { ARAÇ SAYIM TUTANAGI }\end{array}$}} \\
\hline TARIH & \multirow{2}{*}{\multicolumn{2}{|c|}{$\begin{array}{c}5.5 .2018 \\
20: 00-21: 00\end{array}$}} & & \\
\hline SAAT & & & & \\
\hline HAVA DURUMU & \multicolumn{2}{|c|}{$13^{\circ}$} & & \\
\hline \multicolumn{5}{|c|}{ 100.YIL DÖNEL KAVȘAĞI ARAÇ SAYIM TUTANAĞI } \\
\hline AKIȘ YÖNÜ & $\begin{array}{c}\text { OTOMOBIL/TAKSI/ } \\
\text { KAMYONET/PANELVAN }\end{array}$ & \begin{tabular}{|c|} 
KISA \\
OTOBÜS/MINIBÜS/S \\
ERVIS/MIDIBǗs
\end{tabular} & S $\begin{array}{c}\text { KÖRÜKLÜ OTOBÜS/TIR/KAMYON/iș } \\
\text { MAKINESİUZUN OTOBÜS }\end{array}$ & TOPLAM \\
\hline $\begin{array}{l}1-1 \text { YÖNǗ } \\
\text { (U DÖNUUSS) }\end{array}$ & 6 & 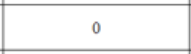 & 1 & 7 \\
\hline 1-2 YÖNÜ & 127 & 55 & 13 & 195 \\
\hline 1-3 YÖNŨ & 195 & 5 & 7 & 207 \\
\hline 1-4 YÖNÜ & 90 & 4 & 9 & 103 \\
\hline 2-1 YÖNUี & 89 & 11 & 10 & 110 \\
\hline $\begin{array}{l}\text { 2-2 YÖNÜ } \\
\text { (U DÖNÜSS) }\end{array}$ & 20 & 0 & 8 & 28 \\
\hline 2-3 YÖNÜ & 264 & 127 & 77 & 468 \\
\hline 2-4 YÖNŬ & 101 & 62 & 17 & 180 \\
\hline 3-1 YÖNÜ & 69 & 38 & 4 & 111 \\
\hline 3-2 YÖNUี & 189 & 106 & 39 & 334 \\
\hline $\begin{array}{l}\text { 3-3 YÖNÜ } \\
\text { (U DÖNÜȘ) }\end{array}$ & 47 & 3 & 0 & 50 \\
\hline 3-4 YÖNŬ & 140 & 36 & 1 & 177 \\
\hline 4-1 YÖNŬ & 61 & 28 & 12 & 101 \\
\hline 4-2 YÖNŬ & 156 & 36 & & 192 \\
\hline 4-3 YÖNÜ & 124 & 50 & 5 & 179 \\
\hline $\begin{array}{l}\text { 4-4 YÖNÜ } \\
\text { (U DÖNÜȘ) }\end{array}$ & 11 & 5 & 0 & 16 \\
\hline TOPLAM & 1689 & 566 & 203 & 2458 \\
\hline
\end{tabular}

\section{Traffic Volume Routes as Percentage}

Percentage of vehicle volumes are prepared in the direction of the counts between 20:00 and 21:00 on weekdays and are shown in Figure 5. The hourly traffic volume of the intersection line 1 is 499 and is distributed to the other arms in percentages as shown in Figure 5a. The hourly traffic volume of the intersection line 2 is 678 , which is distributed to the other arms in percentages as shown in Figure 5b. The hourly traffic volume of intersection line 3 is 667 , which is distributed to the other arms in percentages as shown in Figure 5c. The hourly traffic volume of intersection line 4 is 509 , which is distributed to the other arms in percentages as shown in Figure $5 \mathrm{~d}$.

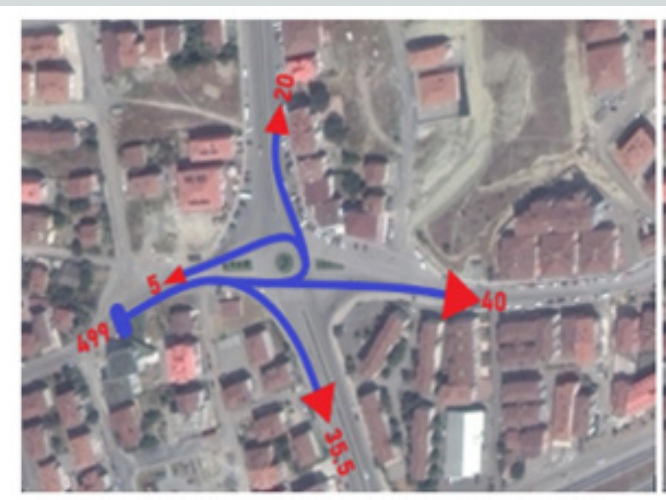

(a) Percentage distribution of volume of $1 \mathrm{arm}$

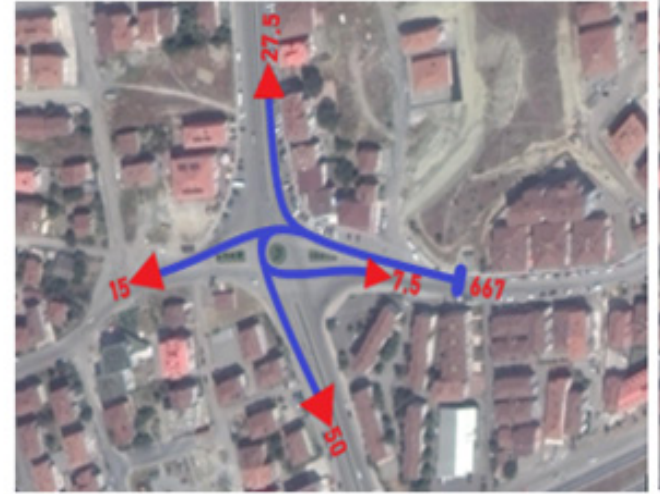

(c) Percentage distribution of volume of 3 arms

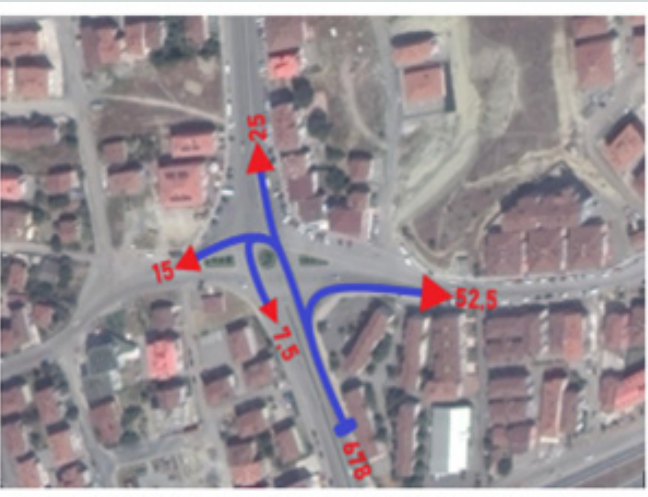

(b) Distribution of percentage of volume of $2 \mathrm{arms}$

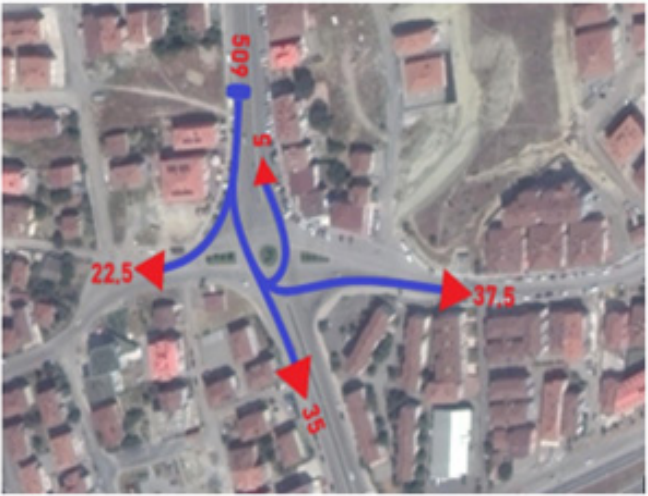

(d) Percentage distribution of volume of 4 arms

Figure 5: Distribution of volumes in arms. 


\section{Civil Engineering Research Journal}

\section{Project Proposal}

The variation of the highest hourly traffic volume observed over the year relative to the average daily traffic is expressed as the k-factor. In general, the 30th highest hour traffic is considered as the peak hour. Although the highest k-factor is often found in recreational areas, this value is recommended

Table 9: Revised average daily traffic (ADT) values. within the city range of 0.7-0.10 [1]. The maximum volume of traffic per hour is generally predicted as $12 \%$ per day in offcities and $10 \%$ in urban main roads [20]. Table 5 was revised based on the assumption that the average hourly average vehicle numbers obtained on the basis of the in-situ counts were $10 \%$ of the daily traffic, the hourly traffic volume was converted to the daily traffic volume and Table 9 was obtained.

\begin{tabular}{|c|c|c|c|c|}
\hline AKIȘ YÖNÜ & $\begin{array}{c}\text { OTOMOBIL/TAKSİ/ } \\
\text { KAMYONET/PANELVAN }\end{array}$ & \begin{tabular}{|c|} 
KISA \\
OTOBÜS/MINIBǗS/S \\
ERVIS/MİiBüS
\end{tabular} & $\begin{array}{c}\text { KÖRÜKLÜ OTOBÜS/TIR/KAMYON/IS } \\
\text { MAKINESĖ/UZUN OTOBÜS }\end{array}$ & TOPLAM \\
\hline $\begin{array}{l}\text { 1-1 YÖNÜ } \\
\text { (U DÖNÜȘ) }\end{array}$ & 60 & 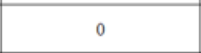 & 0 & 60 \\
\hline 1-2 YÖNÜ & 1210 & 580 & 130 & 1920 \\
\hline 1-3 YÖNÜ & 1950 & 50 & 70 & 2070 \\
\hline 1-4 YÖNÜ & 900 & 40 & 90 & 1030 \\
\hline 2-1 YÖNUี & 900 & 110 & 70 & 1080 \\
\hline $\begin{array}{l}2-2 \text { YÖNÜ } \\
\text { (U DÖNÜSS) }\end{array}$ & 200 & 0 & 80 & 280 \\
\hline 2-3 YÖNÜ & 2640 & 1220 & 770 & 4630 \\
\hline 2-4 YÖNÜ & 1010 & 620 & 170 & 1800 \\
\hline 3-1 YÖNŬ & 690 & 350 & 40 & 1080 \\
\hline 3-2 YÖNUี & 1890 & 1010 & 390 & 3290 \\
\hline $\begin{array}{l}\text { 3-3 YÖNÜ } \\
\text { (U DÖNÜȘ) }\end{array}$ & 460 & 30 & 0 & 490 \\
\hline 3-4 YÖNÜ & 1400 & 360 & 10 & 1770 \\
\hline 4-1 YÖNUี & 610 & 280 & 120 & 1010 \\
\hline 4-2 YÖNÜ & 1500 & 360 & 0 & 1860 \\
\hline 4-3 YÖNÜ & 1210 & 500 & 50 & 1760 \\
\hline $\begin{array}{l}\text { 4-4 YÖNŨ } \\
\text { (U DÖNÜȘ) }\end{array}$ & 100 & 20 & 0 & 120 \\
\hline TOPLAM & 16730 & 5530 & 1990 & 24250 \\
\hline
\end{tabular}

1. Number of Daily Vehicles* $\mathrm{k}=$ Peak Hour Number of Cars (1)

Number of Daily Vehicles $* 0.10=$ the number of daily vehicles there $=24.250$ vehicles $/$ day

2. Number of Annual Cars = Number of Daily Vehicles *365 (2)

Number of Annual Cars $=24.250 * 365=8.851 .250$ vehicles / year

In general, the intersection type selection; construction costs, accident costs, environmental costs, and the duration of the cruise should be considered from a socio-economic point of view. However, in some cases, the choice of intersection type may be based on experience from other similar intersections. So it is not always possible to make socio-economic calculations considering all possible intersection types. It is recommended that the traffic safety dimension is the main criterion. At this point, the safety criterion must first be checked whether the requirements are met or not. Thereafter, it should be checked whether other criteria are acceptable [20]. With regard to the intersection selection model, the following steps in Figure 6 were followed; In the first step, the data obtained in Table 9 were evaluated in the graphical light in Figure 7, and the feasibility of at-grade junction was investigated. As a result, it was found that at-grade junction was possible.

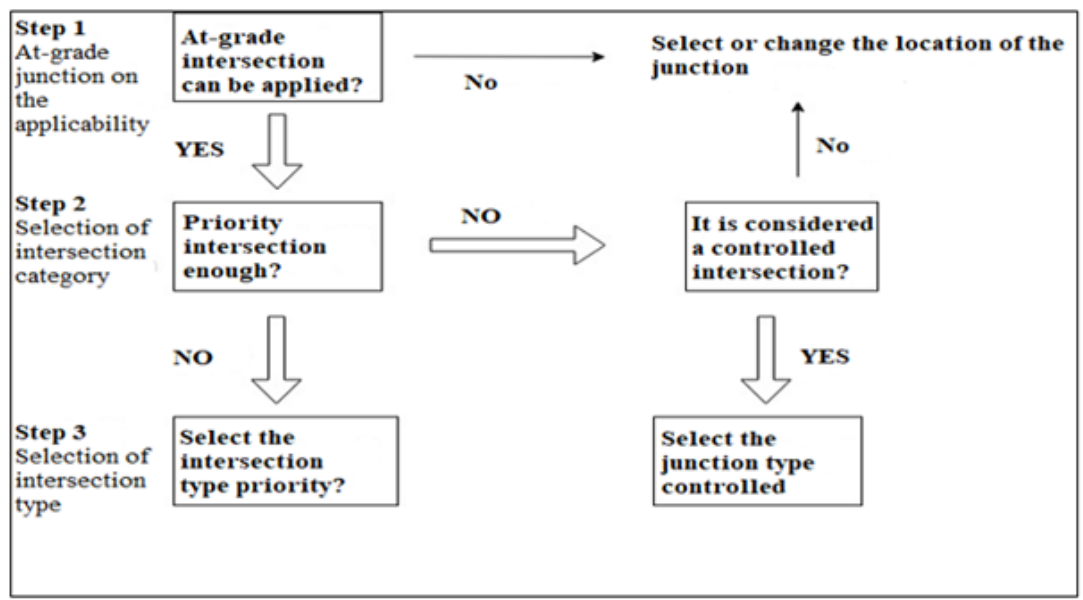

Figure 6: Interchange choice model. 


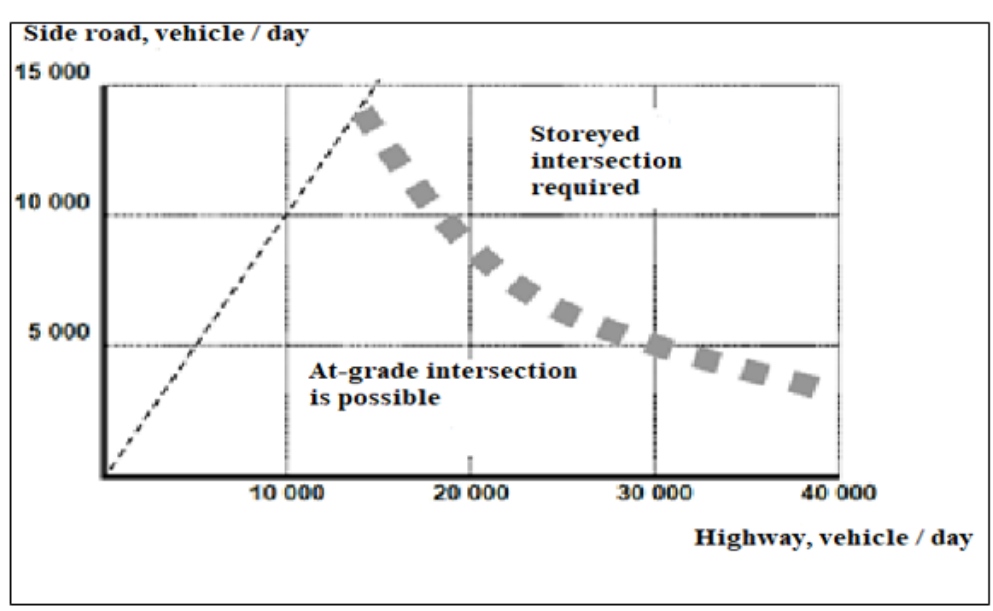

Figure 7: Applicability of at-grade junction [20].

Depending on the traffic patterns of the main traffic route, the intersection can be classified under two main intersection categories. There are many different intersection types for each Table 10: Classification of at-grade junctions.

\begin{tabular}{|c|c|c|c|}
\hline \multirow{2}{*}{$\begin{array}{l}\text { Intersection Ca- } \\
\text { tegory }\end{array}$} & \multicolumn{2}{|c|}{ Traffic Regulation } & \multirow[t]{2}{*}{ Intersection Types } \\
\hline & Highway & Side Road & \\
\hline $\begin{array}{l}\text { Priority Interse- } \\
\text { ction }\end{array}$ & Priority & $\begin{array}{l}\text { Giving way or stop } \\
\text { control }\end{array}$ & $\begin{array}{c}\text { Depending on the use of separate return lanes and traffic islands, various } \\
\text { types }\end{array}$ \\
\hline $\begin{array}{l}\text { Controlled interse- } \\
\text { ction }\end{array}$ & \multicolumn{2}{|c|}{ Giving way or stop control } & Circular junction (Roundabout)Signalized junction \\
\hline
\end{tabular}

category. In Table 10, classification of at-grade junctions is made [20].

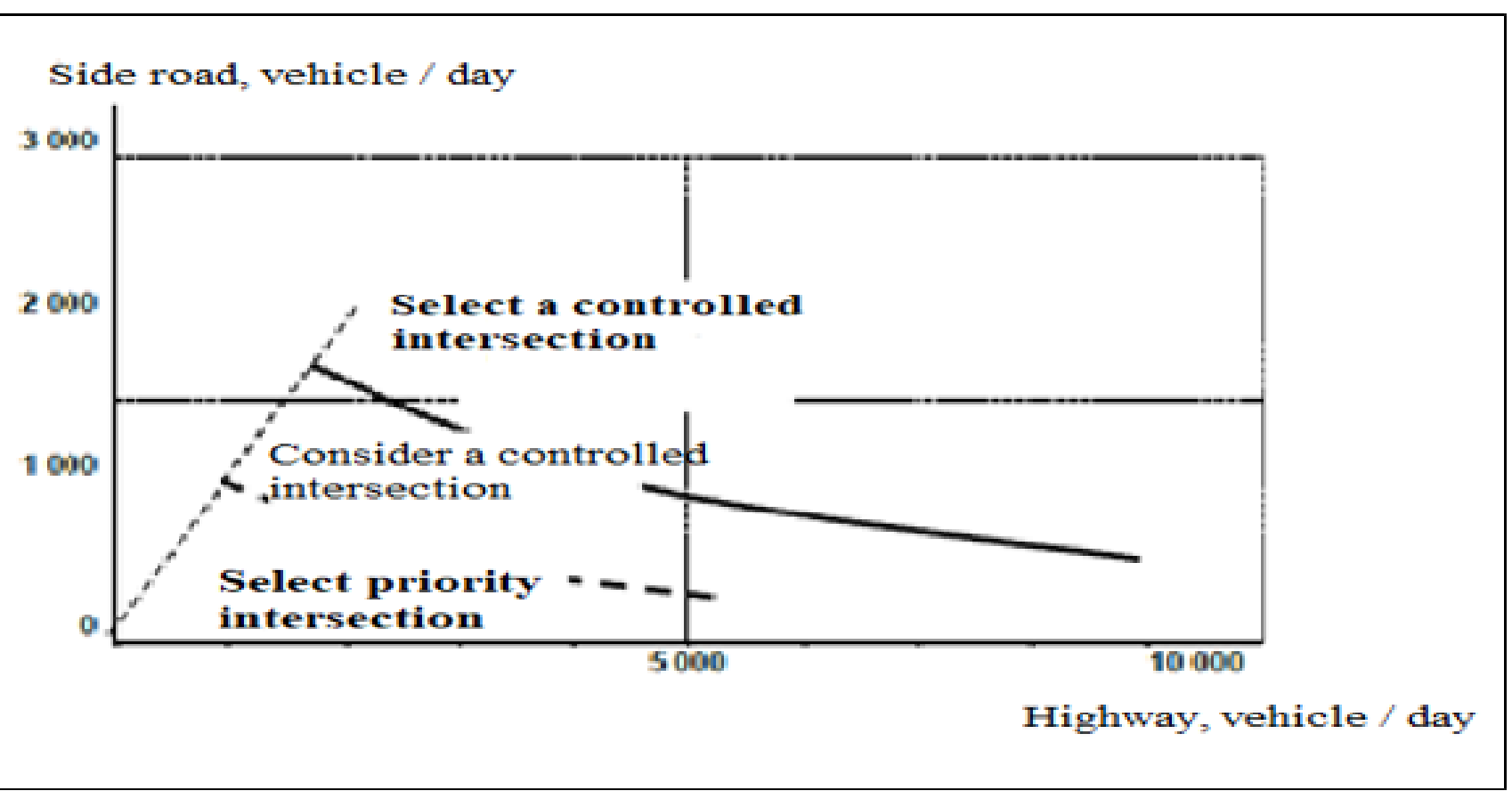

Figure 8: Choice of intersection category for security [20]. 


\section{Civil Engineering Research Journal}

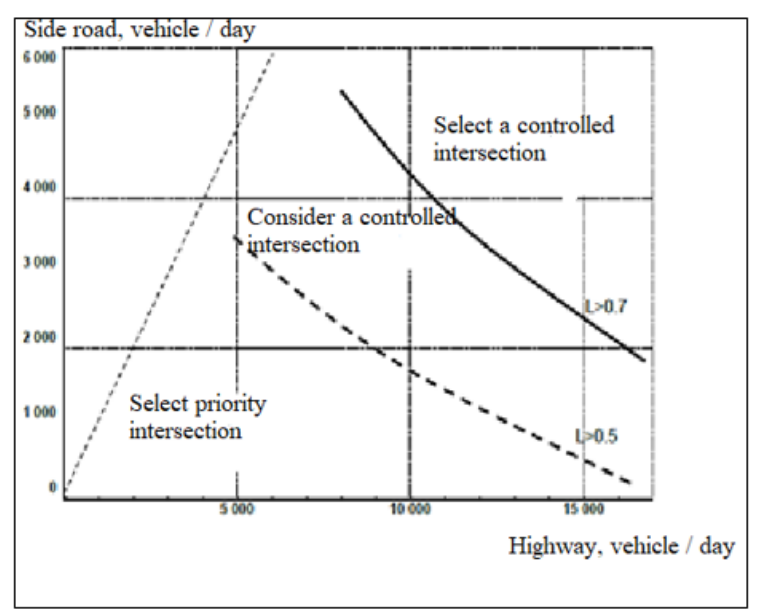

Figure 9: Choice of intersection category in terms of capacity.

As a second step, the feasibility of the primary intersection at $\mathrm{X}$ intersections at a maximum speed of $70 \mathrm{~km} / \mathrm{h}$ will be evaluated both in terms of safety and capacity through Figures $8 \& 9$.

When considered from the security point of view, it is evaluated that the controlled intersection type is more suitable. In terms of capacity, it is seen that the priority intersection can be selected, but it is also seen that the selection of the controlled intersection type is more appropriate.

In the third step, the graphic below is used in the selection of the controlled intersection type. According to these findings; a multilevel junction or a traffic lighted junction is not necessary and the 100. year roundabout has been redesigned as an intelligent roundabout to increase both safety and capacity.

\section{Simulation Study}

PTV Vissim is software that compares intersection geometry, analyzing public transport priority, or fully simulating traffic flows considering certain signalizations. PTV Vissim is a microscale traffic simulation software that can expose all road users (personal vehicles, freight transport, public transport linked by train and road), and their interaction with each other in a single model [21]. In step 4, based on the vehicle volume values and roots, suggestion models were created in the PTV Vissim program. The generated models were simulated through the PTV Vissim program on the intelligent intersection design with geometric arrangement, and the intersection capacity and safety were reduced to the optimum level (Figures 10-13).

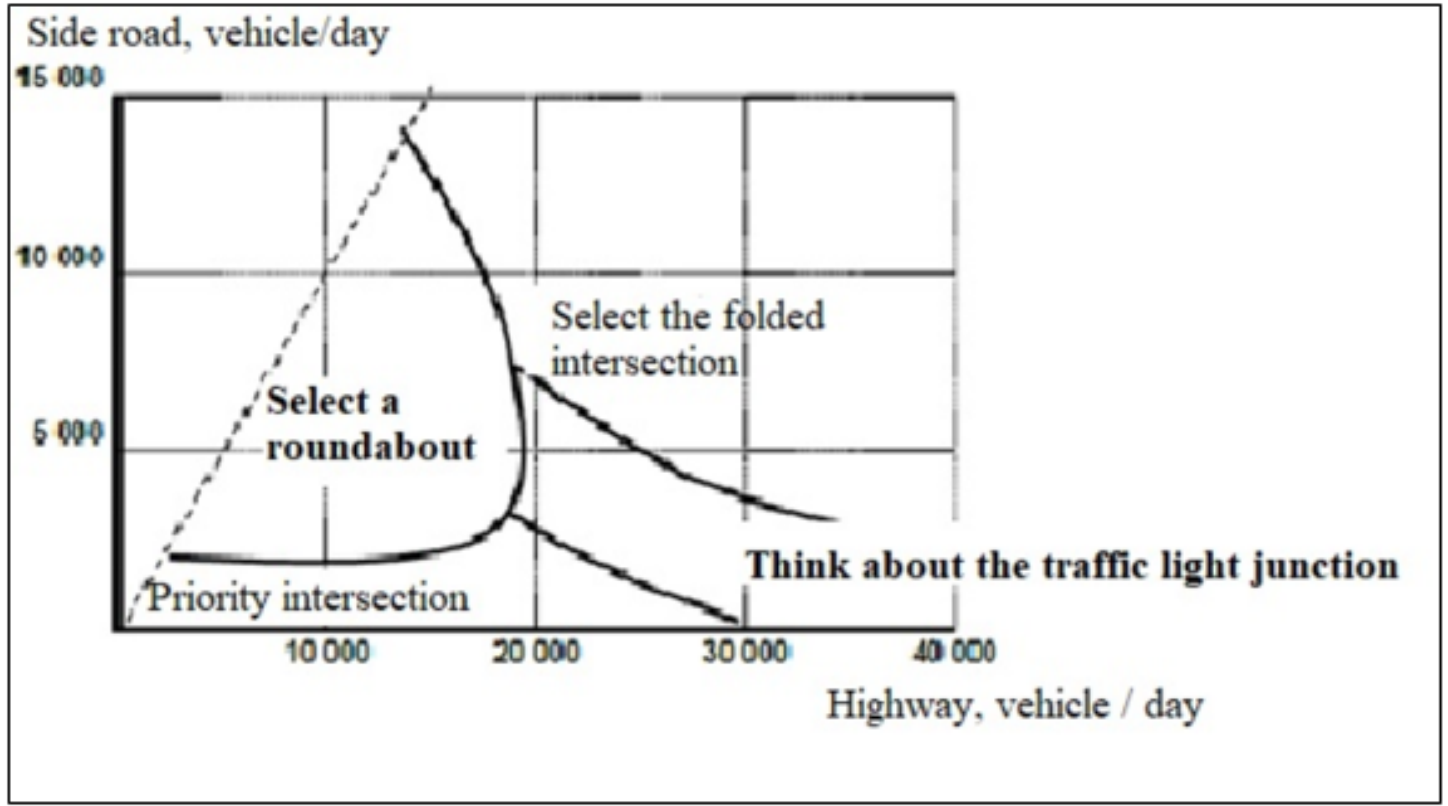

Figure 10: Choice of controlled intersection type. 


\section{Civil Engineering Research Journal}

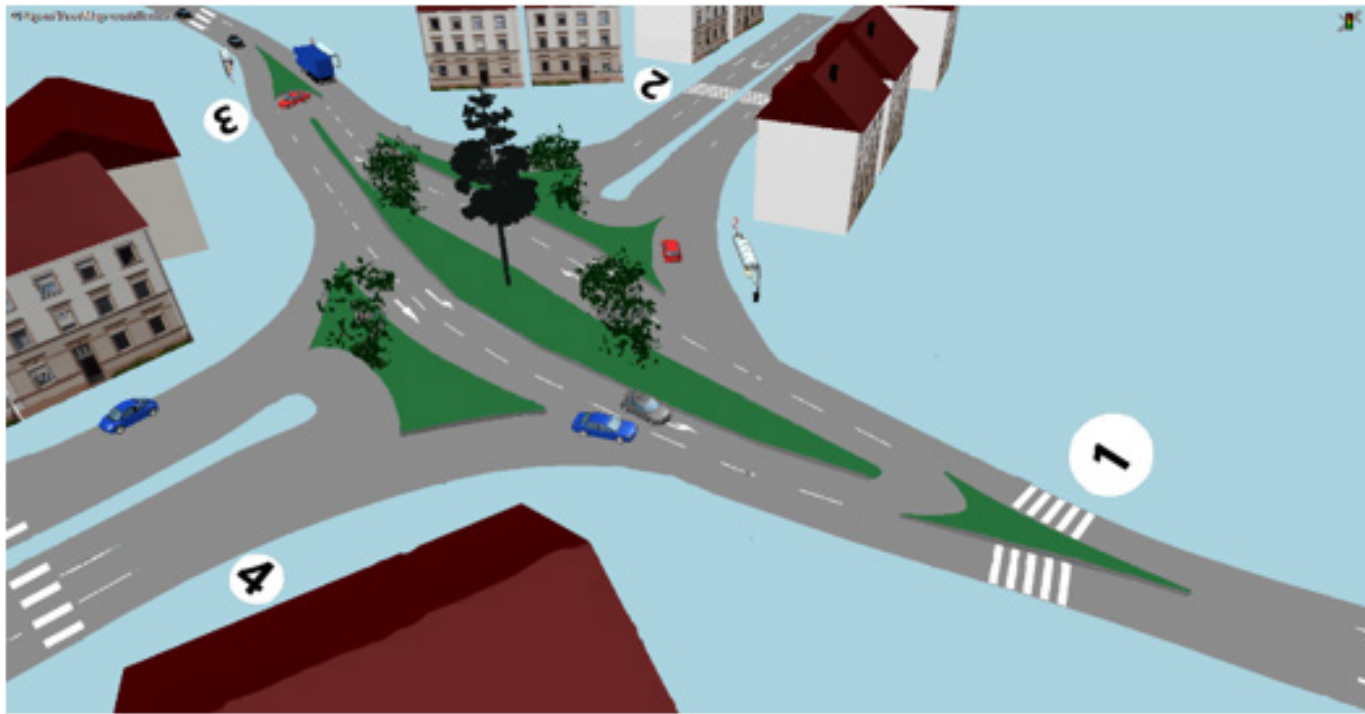

Figure 11: Suggestion intelligent intersection 3D simulation image.

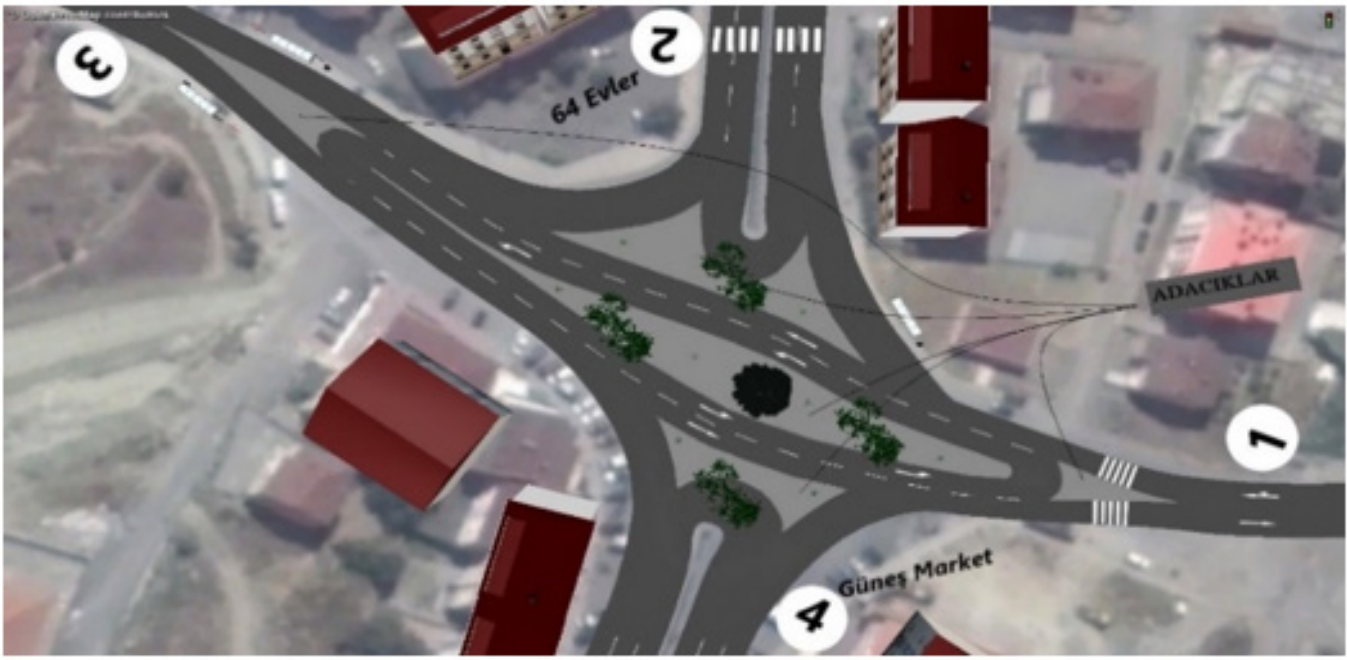

Figure 12: Suggestion intelligent intersection 2D simulation image.

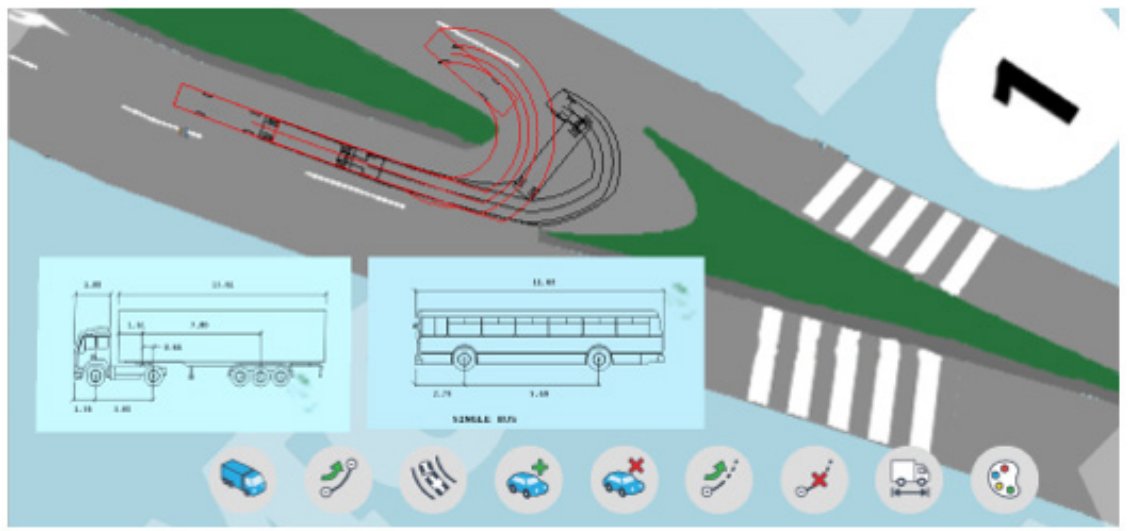

Figure 13: Control of design tool rotations with Auto TURN. 
Autoturn: It is a software that enables design projects to be reliably analyzed by showing the vehicle's entrance and exit, turning points of vehicles, turning radii at intersections, roundabouts, bus terminals, loading areas, park areas and city roads [22]. In the final step, the turn radius of the designed intelligent junction was checked with the Autoturn Program. In the study, two vehicle types, one of which is trailer ant the other is bus for the given dimensions were selected so as to apply a rotation speed of $30 \mathrm{~km} / \mathrm{h}$. As a result of the simulation, it is shown that no problem arises due to the rotation radiuses in the suggestion intelligent intersection design, and no additional geometric arrangement is required.

\section{Results and Discussions}

The existing problems were identified on the basis of traffic counts and field observations on a sample roundabout in Karabük Province, 100.year neighborhood, at the intersection of 1002 Street and 1003 street. A new intelligent roundabout design was applied, and the efficiency of the new intersection model applied was determined by PTV Vissim and optimized using Autoturn software's. On the basis of the vehicle volume values and routes, proposal models were created in the PTV Vissim program and the generated models were simulated by the PTV Vissim program on the intelligent intersection design with geometric arrangement and the problems caused by vehicle overlaps, traffic accidents, accidents and pedestrian transitions were reduced to optimum levels, safety has been increased.

The turn radius of the designed intelligent junction was checked with the Autoturn Program. In the study, two types of vehicles, one trailer and the other a bus, were selected to have speeds of $30 \mathrm{~km} / \mathrm{h}$. As a result of the simulation, it is shown that no problem arises due to the rotation radiuses in the suggestion intelligent intersection design, and no additional geometric arrangement is required. Horizontal and vertical signings must also be done in order to be practiced or on-site application. Experimental results show that the intersection design should be designed considering the parameters of each intersection instead of standardization and new approaches in intersection design (intelligent intersection etc.) should be adopted.

\section{References}

1. (2005) KGM Karayolu Tasarım El Kitabı, Ankara.

2. Saplı oğlu M, Karaşahin M (2010) Şehirci Kontrolsüz Eșdüzey Kavşak Kazalarını Etkileyen Unsurların Değerlendirilmesi. SDU International Technologic Sciences 2(2): 26-49.
3. (2017) European Road Safety Observatory. Traffic Safety Basic Facts 2017 Junctions. SafetyNet, European Commission.

4. http://ec.europa.eu/transport/road_safety/specialist/statistics/ care_repo rts_graphics/index_en.htm.

5. Kuciemba SJAC (1992) Safety effectiveness of highway design features Intersections, Report No. FHWA/RD-91/048, Federal Highway Administration, 5 .

6. Jason Mc Conachy, Robert E (2002) Spicher National Highway R\&T Partnership Initiative. A report of the National Highway R\&T Partnership.

7. Arslan F, Karayolu (2012) Trafik Güvenliği Sempozyumu 3.

8. (2017) KGM, Trafik Güvenliği Dairesi Başkanlığı. Trafik Kazaları Özeti. Ankara.

9. (2016) KGM, Karayolları Genel Müdürlüğü Sorumluluğundaki Yol Ağında Meydana Gelen Trafik Kazalarına Ait Özet Bilgiler. Ankara.

10. Flannery A (2001) Geometric Design and Safety Aspects of Roundabouts. Transportation Research Record 1751 Paper no. 010425 .

11.https: / / www.fhwa.dot.gov/publications /research / safety/00067/000675.pdf.

12. Gates T, Maki R (2000) Converting Old Traffic Circles to Modern Roundabouts: Michigan State University Case Study.

13. Sisiopiku V, Oh H (2001) Evaluation of Roundabout Performance Using Sidra, Journal of Transportation Engineering.

14. Tollazzı T, Renčelj M, Turnšek S (2011) New Type of Roundabout: Roundabout with depressed lanes for right turning- flower roundabout. Traffic \&Transportation 23(5): 353-358.

15. Gross F, Lyon C, Persaud B, Srinivasan R (2013) Safety Effectiveness of Converting Signalized intersections to roundabouts. Accident Analysis \& Prevention 50: 234-241.

16. DeArgao P (1992) Circles and roundabouts. Institute of Transportation and Planning, Swiss Federal Institute of Technology, Lausanne, Switzerland.

17. Arıkan Öztürk E, Cubuk MK, Arslan D, Yüksel E (2007) Modern Dönel Kavşakların Kapasite ve Güvenlik Yönünden İncelenmesi, Gazi Üniversitesi Mühendislik - Mimarlık Fakültesi Dergisi 22(4): 917-926.

18. Tunç A (2003) Trafik Mühendisliği ve Uygulamaları, Asil Yayın Dağııım, Ankara.

19. Aydemir T, Tanyel S (2005) Çok Șeritli Dönel Kavșaklar Üzerinde OD matrisinin etkisi. 6. Ulaştırma Kongresi, TMMOB İnşaat Mühendisleri Odası İstanbul Şubesi, İstanbul.

20. Karayolu İyiliştirme ve Trafik Güvenliği Projesi, Karayolu Tasarım Raporu, SweRoad, Ankara 2001.

21. http://vision-traffic.ptvgroup.com/en-us/products/ptv-vissim/

22. http://www.transoftsolutions.com/vehicle-swept-path/autoturnselect/autoturn/ 


\section{Civil Engineering Research Journal}

This work is licensed under Creative
Commons Attribution 4.0 License
DOI: 10.19080/CERJ.2019.09.555758

Your next submission with Juniper Publishers will reach you the below assets

- Quality Editorial service

- Swift Peer Review

- Reprints availability

E-prints Service

- Manuscript Podcast for convenient understanding

- Global attainment for your research

- Manuscript accessibility in different formats

( Pdf, E-pub, Full Text, Audio)

- Unceasing customer service

Track the below URL for one-step submission https://juniperpublishers.com/online-submission.php 